\title{
Quantifying the Impact of Services Liberalization in a Developing Country
}

\author{
Denise Eby Konan \\ Department of Economics, University of Hawaii, Honolulu, HI 96822 \\ Phone 808-956-5971 Fax 808-956-7115 Email konan@hawaii.edu
}

\author{
Keith E. Maskus \\ Department of Economics, Box 256, University of Colorado, Boulder, CO 80309 \\ Phone 303-492-7588 Fax 303-492-8960 email maskus@colorado.edu \\ and \\ World Bank, 1818 H Street NW, Washington, DC 20433 \\ Phone 202-473-4460 Fax 202-522-1159 Email kmaskus@worldbank.org
}

JEL Classification: C68, F13, F14, F23, L8

Keywords: Liberalization, Services, Regulation, Computational Economics, Tunisia

World Bank Policy Research Working Paper 3193, January 2004

The Policy Research Working Paper Series disseminates the findings of work in progress to encourage the exchange of ideas about development issues. An objective of the series is to get the findings out quickly, even if the presentations are less than fully polished. The papers carry the names of the authors and should be cited accordingly. The findings, interpretations, and conclusions expressed in this paper are entirely those of the authors. They do not necessarily represent the view of the World Bank, its Executive Directors, or the countries they represent. Policy Research Working Papers are available online at http:/lecon.worldbank.org.

We gratefully acknowledge Sherry Stephenson, Bernard Hoekman, Mohamed Goaied, and Dominique van der Mensbrugghe for valuable discussions throughout the writing of this paper, and Aristomene Varoudakis for his comments. We also thank Robert Lipsey, Asim Erdilek, and other participants at the 2001 Western Economics Association annual conference for constructive comments. 


\begin{abstract}
The authors consider how service liberalization differs from that of goods liberalization in terms of welfare, the levels and composition of output, and factor prices within a developing economy, in this case Tunisia. Despite recent movements toward liberalization, Tunisian service sectors remain largely closed to foreign participation and are provided at high cost relative to many developing nations. The authors develop a CGE model of the Tunisian economy with multiple products and services and three trading partners. They model goods liberalization as the unilateral removal of product tariffs. Restraints on services trade involve both restrictions on cross-border supply (mode 1 in the GATS) and on foreign ownership through foreign direct investment (mode 3 in the GATS). The former are modeled as tariff-equivalent price wedges while the latter are comprised of both monopoly-rent distortions (arising from imperfect competition among domestic producers) and inefficiency costs (arising from a failure of domestic service providers to adopt least-cost practices).

They find that goods-trade liberalization yields a modes gain in aggregate welfare and reorients production toward sectors of benchmark comparative advantage. However, a reduction of services barriers in a way that permits greater competition through foreign direct investment generates large welfare gains. As a result, service liberalization requires lower adjustment costs, measured in terms of sectoral movement of workers, than does goods-trade liberalization. Moreover, it tends to increase economic activity in all sectors and raise the real returns to both capital and labor. Overall welfare gains of comprehensive service liberalization amount to over five percent of initial consumption. The bulk of these gains come from opening markets for finance, business services, and telecommunications. Because these are key inputs into all sectors of the economy, their liberalization cuts costs and drives larger efficiency gains overall. The results point to the potential importance of deregulating services provision for economic development.
\end{abstract}




\section{Introduction}

The dramatic economic growth that visited much of the world in the 1990s has been attributed often to a 'new economy' arising from global integration. Yet, the economies of many developing countries in Africa and Latin America experienced slower growth or remained stagnant. This history is puzzling as there has been an unprecedented willingness on the part of many developing economies to participate in the globalization of merchandise trade. Through both unilateral trade liberalization and agreements reached in the World Trade Organization and regional trade accords, many countries sharply lowered manufacturing tariffs and other impediments to goods trade. Nevertheless, as Rodrik (2001) has pointed out, traditional trade liberalization seems not to have fully delivered on its promise for prosperity. In this paper we suggest that part of the explanation for this weak performance rests in the continued insulation, and resulting poor condition, of the domestic services sectors in many developing countries. These service sectors tend to deliver high-cost and unproductive input services to export industries, thereby limiting economic efficiency gains from trade reform. We explore this claim in a computational general equilibrium model of the Tunisian economy.

The mechanisms by which services trade liberalization might improve welfare differ from those of goods trade. As is well known, producers respond to a lowering of border barriers in products by reorienting production towards goods in which an economy possesses a comparative advantage. Goods trade thus involves a restructuring of the economy as labor and capital move out of import-competing sectors and into export sectors. Goods trade also tends to redistribute income, with abundant factors benefiting disproportionately from liberalization in the long run.

In contrast, trade in services is not solely a cross-border phenomenon. As the paper by Markusen, Rutherford and Tarr (1999) points out, many foreign services are best transferred through foreign direct investment (FDI) due to the personal contact that is often required between 
the service provider and client. Restrictions on FDI or the movement of professional personnel may reduce services trade far more than tariffs or other border barriers limit trade in goods.

Indeed, in many developing countries, Tunisia included, laws and regulatory agencies erect entry barriers that essentially rule out FDI in key service sectors.

Foreign direct investment involves inflows of capital and personnel, but more importantly for developing countries it also tends to embody transfers of technology that can upgrade productivity in the domestic economy. Because financial, communications, and professional services are key intermediate inputs into production in all sectors, technological improvements in these sectors could have the effect of upgrading overall productivity. Thus, whereas liberalizing goods trade moves an economy toward specialization, liberalizing services trade through permitting foreign establishments could lead to more balanced output expansion.

In industrialized countries certain producer services are among the largest and most dynamic components of production and employment. For example, technological innovations in information management and telecommunications services have facilitated the global transactions upon which the "new economy" has thrived (Lipsey, 2001).

This situation lies in stark contrast with Tunisia, where there is a large state presence in many key service sectors. Regulatory agencies limit competition by restricting markets available to producers. Foreign participation is also highly restricted and often limited to the services of non-resident Tunisian suppliers. As we discuss below, anecdotal evidence indicates that Tunisia's communication, financial, insurance, distribution, and professional services are expensive, of poor quality, and often inaccessible. An inefficient service sector acts as a drag on the entire economy, and especially on trade, as services are critical inputs in production and distribution processes.

In some respects, Tunisia has pursued a strategy of liberalization and alignment with the global economy. However, Tunisia's 1995 commitments under the General Agreement on Trade 
in Services (GATS) are few and generally represent a preservation of status quo policies. ${ }^{1}$ The opening of services markets to foreign suppliers would also involve privatization and deregulation. Policymakers are concerned about whether the economic benefits would justify the adjustment costs involved. Moreover, Tunisian services are supplied by important domestic interests, which makes liberalization difficult to undertake without some indication of the potential for gains and information on their likely distribution.

Unfortunately, there are very few empirical studies on services trade and FDI, in part due to a variety of measurement problems. It is against this backdrop that the present study is conducted. We employ a computable general equilibrium (CGE) model to compare the impact of service liberalization to that of trade liberalization. We follow GATS definitions and consider, separately, liberalization of both cross-border services trade (mode 1) and the establishment of domestic presence by foreign direct investment (mode 3). For this purpose we develop estimates of the distortions that the present, relatively closed, environment in Tunisia imposes on the price of services. By simulating the effects of removing these distortions, we are able to quantify the impacts of liberalization. The potential efficiency gains would be large, while output in all merchandise sectors would rise, after services liberalization. Furthermore, the real prices of both capital and labor would increase.

\section{Conceptual Issues}

Trade in services is distinguished from trade in goods by the intangible nature of many transactions. Unlike physical goods, which must cross borders and thus are subject to customs procedures and tariffs, services often involve direct transactions between the consumer and producer. This complicates the measurement of both service flows and their corresponding impediments. The founders of the GATS framework recognized the importance of the various channels by which services are transacted. GATS identifies four modes of supply: cross-border

\footnotetext{
${ }^{1}$ Of the twelve service sectors defined under the GATS classification scheme Tunisia made commitments
} 
supply (mode 1), consumption abroad (mode 2), commercial presence (mode 3), and the presence of natural persons (mode 4). Thus GATS extends traditional trade law to include both foreign direct investment (mode 3) and movements of labor (mode 4).

Unfortunately, these legal definitions do not accord well with present international balance of payments accounting practices, as discussed in detail by Karsenty (2000), making difficult the measurement of services trade and its components. Equally problematic is the measurement of impediments to services trade. Warren and Findlay (2000) and Hoekman (2000) provide excellent surveys of these measurement issues. For example, Hoekman (1995) developed a frequency indicator as an initial attempt to quantify the presence of barriers based on the GATS schedule of commitments by country. While this provides some indication of the extent of commitments, the index is not designed to measure the level of barriers present. Francois (1999) estimates a gravity model of services trade, adopting Singapore and Hong Kong as free-trade benchmarks. In his approach, discrepancies in predicted trade patterns are used to indicate the severity of policy barriers. Warren and Findlay (2000) describe an ongoing Australian services research project that is attempting to measure the wedge between price and marginal cost in service sectors in order to get an indication of the impact that impediments might have on prices. The project also seeks to develop quantity impact measures by comparing domestic output to international standards. Unfortunately, the study is incomplete and ultimately may not provide information that could be applied to developing economies.

Given severe data limitations, there are very few econometric studies on services trade and their barriers. One advantage of a CGE model is that it can provide quantifiable insights with relatively sparse datasets. Several studies of services barriers exist using the GTAP multi-country database. $^{2}$ An early model by Brown, et al (1996) converts Hoekman's frequency indices into an approximation of cross-border barriers to services trade and simulates liberalization in the multi-

in only three: financial services, tourism, and telecommunications. These commitments reflect little more than a codification of Tunisia's present legal system. 
country Michigan model. Hertel (2000) approximates cross-border barriers with the gravityequation estimates of Francois and treats liberalization as an elimination of resource-using barriers. A significant limitation of these models is that they do not capture the potential benefit of FDI liberalization.

More recently, FDI has been incorporated into multi-country GTAP-based models (Dee and Hanslow, 2001; Brown and Stern, 2001). FDI is treated as a capital flow and barriers to the right of establishment are modeled as taxes on the existing investment flow and on local sales. Liberalization (removal of the tax) results in a global reallocation of capital as sector-level rates of return adjust to a new equilibrium. This approach represents a significant improvement over earlier work, which focused only on cross-border trade (Mode 1).

Nonetheless, although these models inform our understanding of global impacts of GATS, they are not adequate for understanding domestic impacts in such highly regulated developing economies as Tunisia for two reasons. First, service sectors that experience no FDI in the benchmark economy are assumed to be non-tradable and could not, therefore, be recipients of FDI in counterfactual scenarios. Yet in Tunisia, we might reasonably expect that FDI would occur in several important sectors (such as telecommunications or insurance) in which, under current policy, foreign suppliers are simply not permitted to serve Tunisian residents. Existing methodologies do not offer a reasonable way to predict how responsive sectors that are inactive in the benchmark would be to FDI in a liberalized environment. Second, the market structure in most service sectors in Tunisia is highly regulated and imperfectly competitive, perhaps best characterized as cartels. As Francois and Wooten (2001) discuss, shallow liberalization without deregulation could involve essentially an invitation to foreign firms to join the cartel. Deeper liberalization, involving also deregulation permitting new entry, should bring about a more competitive market structure than envisioned in earlier models.

\footnotetext{
${ }^{2}$ See Dee, et al (2000) for an excellent survey of this literature.
} 
An additional point of departure for our work is to consider the impact of services liberalization on the structure of Tunisia's economy relative to that of trade liberalization. The Tunisia input-output table allows us to disaggregate services into 15 sectors. We consider the regulatory environment at a disaggregated level and are able to compare the relative impact of liberalization in individual service sectors. With data on the manner in which services act as intermediate inputs, our simulations are indicative of how service liberalization may restructure the domestic economy.

\section{The Model and Benchmark Data}

Services play a significant role in the Tunisian economy, as is evident from Table 1. Nearly half of all output (excluding tourism) is comprised of services. Output of commercial services has been growing at a faster rate than that of goods. Services make up one-third of household consumption and eighteen percent of intermediate demand according to the 1995 input-output table (Institute National de la Statistique, 1998). Of the tradable services, tourism plays the most significant role, representing over fifteen percent of imports and more than 19 percent of all exports. Tourism export services are considered to be rather open. ${ }^{3}$

There is no statistical information on the importance of FDI in Tunisian services trade, as the earnings and sales of foreign-owned subsidiaries are not reported separately from those of domestic firms. However, foreign participation clearly is minimal in the main service activities in Tunisia. This is due to a variety of investment measures, exchange controls and limits on movement of foreign personnel. The most important restriction is the Foreign Commercial Activities Law of 1961 (Decree Law Number 61-14), by which non-Tunisians are required to obtain a trader's permit, carte de commercant, to engage in any form of commercial activity. This permit, granted on a discretionary basis, has effectively precluded foreign participation in most wholesale and retail markets. The Investment Code of 1993 is also an important barrier to

\footnotetext{
${ }^{3}$ Tourism may be exported without being produced because tourists are treated as "foreign consumers" in
} 
majority foreign equity projects, with foreign entry requiring approval by regulatory councils.

Such approvals are rare and FDI is strictly controlled.

We employ what is, in most respects, a standard CGE model of a small open economy. The full model is discussed below and presented in a technical appendix. Our contribution is in the explicit treatment of services production and investment. Production decisions in the services sector are distorted by regulations that raise entry costs and limit the rights of foreign enterprises to establish facilities in Tunisia. In principle, this restriction distorts prices and quantities through two primary channels. One is the cartel effect whereby barriers to FDI and excessive regulation limit both domestic and foreign participants in certain service sectors, thus hampering competition and supporting market power on behalf of local firms. This market power creates the opportunity in sector $i$ to charge price markups $v_{i}$ over marginal cost $c_{i}$.

$$
c_{i}\left(1+v_{i}\right)=p_{i}
$$

The markup depends on the number of firms, price elasticity of demand, and conjectures about reactions of rival firms. We assume that the rents generated by markups accrue to the representative agent.

Second is a cost inefficiency effect. Marginal costs in a regulated environment may be excessively high as low-cost foreign suppliers are excluded from the market. Additionally, domestic suppliers may be forced to absorb into their costs various regulations on provision and bureaucratic procedures. These activities do not contribute to output and generate pure economic waste (Hoekman and Konan 2001). Thus, resource-using service barriers $\lambda_{\mathrm{i}}$ raise marginal costs above 'best practice' marginal $\operatorname{costs} c_{i}{ }^{*}$ that would prevail in a liberalized environment.

$$
c_{i}^{*}\left(1+\lambda_{\mathrm{i}}\right)=c_{i}
$$

the input-output table and enter as a component of final demand. The production of tourism services exists in the other service sectors, such as transportation, hotels, and restaurants. 
Combining equations (1) and (2) shows that the wedge between price and true marginal costs depends on the product of an ad valorem markup and a proportionate waste factor. Ultimately it would be preferable and interesting to locate empirical information on these two wedges in each sector in order to simulate the effects of their separate and joint removal. Unfortunately, we only have estimates of the entire price-cost wedge and cannot perform this decomposition except on assumed shares. Thus, throughout the baseline counterfactual scenarios, it is assumed that barriers to FDI generate wedges consisting of half rents and half waste.

Services liberalization involves presenting a domestic cartel the possibility of competitive markets with foreign entry. It is important to note that liberalization does not, in our model, generate endogenous changes in FDI flows. Rather, the scenarios involve changes in ownership and market structure in ways that improve efficiency and alter the distribution of rents. This assumption reflects the fact that in several service sectors there is no foreign participation (that is, FDI) in the benchmark equilibrium. In that context it is impossible to determine what the impact of liberalization would be on "marginal" FDI flows, which would not be meaningful. It also permits us to retain a fixed aggregate capital stock in the model, rather than engaging in dynamic simulations of endogenous investment and capital allocation. In this context, the estimates of welfare changes from liberalization of establishment rules are likely to be understated relative to full long-run gains. ${ }^{4}$

Model equations are presented in the appendix and the model is depicted in Figure 1. We assume that production of agricultural, mineral, and manufacturing goods is characterized by constant returns to scale and perfect competition, implying that prices equal marginal costs of output. ${ }^{5}$ Services production is subject to constant returns as well, though in the initial

\footnotetext{
${ }^{4}$ Kehoe (2002) discusses the importance of incorporating changes in trade and investment flows in sectors where they had been absent in the computation of new equilibrium outcomes. This observation stems from the chronic tendency of CGE models of NAFTA to underpredict the ultimate impacts of that trade agreement on Mexico's international trade and investment.

${ }^{5}$ This assumption is standard in the literature. See, for example, Konan and Maskus (2000).
} 
benchmark it is monopolized as discussed above. ${ }^{6}$ In all sectors, production functions are approximated with Leontief technologies using composite intermediate inputs and real value added. A constant elasticity of substitution (CES) production function describes the substitutability between labor and capital inputs in producing real value added. Intermediate inputs and final goods are differentiated by country of origin according to the Armington assumption, so that export and import prices differ across regions. ${ }^{7}$ The three trading regions are the European Union (EU), the Arab League countries, and the rest of the world (ROW). In each sector, demand for domestically produced and imported goods is represented by a CES function, and intermediate imports are also differentiated across regional sources of supply in a CES structure. Similarly, Tunisian industries supply regionally differentiated goods to both domestic and foreign markets (exports). Production follows a nested two-stage constant elasticity of transformation (CET) function. Total output is first calculated as the sum of domestic supply and total exports, with the latter then being allocated across the same destination regions according to a sub-CET function. Capital and labor are assumed to be freely mobile across sectors, implying that our simulations pertain to long-run outcomes of liberalization.

A representative consumer maximizes a nested CES utility function with a corresponding multi-staged budget constraint. In the first stage, the consumer decides how much to spend on goods from each sector, given the budget constraint. Income elasticities across sectors are set at unity as given by a Cobb-Douglas (CD) utility nest. In the second nest, the consumer determines domestic and aggregate import expenditures in each sector according to a CES function. Then given a budget for imports, the consumer selects purchases of imports from each region. These latter functions also characterize the split between government consumption and investment

\footnotetext{
${ }^{6}$ It is likely that a number of services, such as telecommunications, transport, and finance, are subject to economies of scale and scope. Thus, our assumption of constant returns may understate the gains from liberalization.

${ }^{7}$ De Melo and Robinson (1989) show that models that allow product differentiation are well behaved under a small open economy assumption; in effect the economy is a price taker at the level of aggregate trade flows and each region's aggregation is sufficiently distinctive to support the Armington assumption.
} 
spending on domestic and imported goods and services. The representative consumer receives income from primary factors (labor and capital), net transfers from the government, the currentaccount deficit, and any net economic rents from the operation of restrictions on services trade.

Two standard closure rules are imposed: the savings-investment balance and a fixed current account balance. The savings-investment balance is based on the assumption that the capital stock is exogenously fixed at the benchmark level. This stock is financed through forced consumer savings that acts as a direct (lump-sum) tax. The interest rate (an index price of the composite capital stock) is endogenous and determined by factor demand conditions. The current-account is defined as the sum of the merchandise trade balance, the services balance, net foreign worker remittances, and (negative) net payments on foreign capital. ${ }^{8} \mathrm{We}$ assume that foreign reserves will be held constant so that the current account will be just offset by (the negative of) the capital account. The current-account balance itself is held constant in real terms throughout the simulations. Income from foreign remittances less foreign capital payments enters as an exogenous addition to the representative agent's income. To hold the current account balance fixed while international prices are constant requires a balancing item. This is accomplished by means of a change in the home "real exchange rate," which refers implicitly to a change in the home price index (generated by changes in price of home-produced goods) sufficient to sustain a constant current-account balance as import and export volumes change.

The government budget deficit is a deduction in available income for the representative agent, constituting a transfer to government consumption. The deficit is held fixed during our simulations. Thus, if a policy reform causes prices to fall, thereby reducing the tax revenues required to finance government expenditures, this tax saving is transferred to the representative agent. At the same time, if trade liberalization results in lost tariff revenues, the revenues are recouped by means of allowing household lump-sum tax rates to vary endogenously.

\footnotetext{
${ }^{8}$ In the 1995 benchmark year, foreign remittances were approximately 650 million Dinars while net capital
} 
The data for the model consist of a Social Accounting Matrix (SAM) and other parameters, such as import and export trade flows by region, sectoral tax and tariff rates, and elasticities of substitution and transformation. Because there is little empirical evidence on relevant elasticities for the Tunisian market, we make standard assumptions about their values. In particular, labor-capital substitution is set at unity in a Cobb Douglas value added production function. Benchmark trade elasticities are drawn from Rutherford, Rutstrom and Tarr (1995) and Konan and Maskus (2000). The various trade elasticities are 2.0 for substitution between domestic and imported goods, 5.0 for substitution among regional imports and for transformation between domestic output and exports, and 8.0 for transformation among regional export destinations. These data are assembled into a consistent set of relationships between intermediate demand, final demand, and value-added transactions using the 1995 input-output table for Tunisia on a diskette provided by the Institut National De La Statistique (INS) along with the 1998 INS Les Comptes de la Nation report.

Trade and tariff data, provided in Table 2, were aggregated to the input-output sectoral basis using import weights consistent with the concordance between the input-output table and the tariff classification. Tariff rates were determined by collections data for 1995 and vary across regions due to duty drawback provisions as well as preferential treatment of the EU and the Arab League. There are no data on tariff collections on services, and we take their tariff rates to be zero.

Table 3 lists our estimate of price wedges due to service barriers, which are the key parameters to be altered in the simulations. Mode 1 barriers on cross-border trade are treated as ad valorem tariff-equivalent NTBs. These are simply set to zero in the liberalization exercises. Sectors that are listed as non-traded (indicated by $n t$ ) remain non-traded post-liberalization. In terms of mode 3, we would ideally like to estimate the impact that services barriers have on both price markups and on resource costs so as to distinguish between the pro-competitive effects and

income totaled negative 680 million Dinars according to the IMF Balance of Payments Statistics Yearbook. 
the cost-reduction effects. Warren and Findlay (2000) suggest computing the pro-competitive impacts using price-cost margins (or "net interest margins"). Ideally, we would also like to capture the cost-reduction effects by comparing actual costs to a constructed estimate of costs if services were provided according to a 'world's best-practice' cost function. Unfortunately, none of these measurements are attainable for Tunisia, as is the case for most countries.

The services barriers given in Table 3 are based on industry studies in Tunisia and extensive discussions with Tunisian industry experts, country economists and government officials and on Zarrouk (2000). The financial services barriers estimates are taken from our observation that the level of monetary intermediation in the banking system is about $30 \%$ lower than in comparable countries (Bahlous and Nabli 2000) and on Goaied's (1999) estimation of the cost inefficiencies in the financial sector. This is in line with the estimates of Kalirajan, et al (2000) for the banking sectors in Chile, Singapore, South Korea, and Thailand. The price wedges in insurance, communications, and transportation reflect the high level of benchmark regulation in those sectors and comparisons with markets in similar countries (Vittas 1995, World Bank 2000). The distribution and retail sectors show large inefficiencies and are very fragmented, making our 5\% inefficiency measure conservative. Many professional services are subject to a nationality requirement, thus restricting foreign participation, and it is possible that our $10 \%$ estimated price wedge is low. While the construction, hotel, and restaurant sectors are viewed here as already substantially liberalized and subject to a small price-cost wedge, foreign participation remains subject to the investment code and projects are granted upon approval of a Cahier des Charges. Remaining sectors (health and education, public services, and other services) are taken to be exempt from potential liberalization. 


\section{Results}

The liberalization scenarios considered can be broken down in several ways. First, liberalization of investment barriers in services is considered. Sensitivity analysis demonstrates the importance of the decomposition of the price wedge into resource-using versus rentgenerating barriers. The second step is to distinguish between liberalization of border barriers and investment barriers, broadly. Next, the impacts of liberalization are broken down on a sectoral basis. The final set of scenarios compares the impact of services liberalization to that of traditional liberalization of trade in goods.

Table 4 presents potential impacts of lifting barriers to foreign investment in services (mode 3 delivery). As discussed in the previous section, investment barriers are assumed to drive an observable wedge between price and marginal cost. Unobserved is the decomposition of the wedge into two sources of distortion: rent-generating (cartel effect) and resource-using (inefficiency effect). Three benchmark possibilities are considered in Table 4. First (column one), assume that the only barrier to foreign investment is one that preserves a domestic cartel and thus generates pure economic rents for Tunisian interests. That is, Tunisian service producers are using world-class technologies and face costs equivalent to those of the low-cost world producer. Upon liberalization, foreign entry is assumed to eliminate the price-wedge as markets become competitive. Domestic rents are completely dissipated to the benefit of Tunisian services consumers. The result is a modest gain in welfare of the representative household of one-third of one percent, measured as equivalent variation in the representative agent's real income.

At the other extreme (column three), assume services markets are perfectly competitive in the benchmark, but that Tunisian firms do not employ world-class production techniques and are thus inefficient. Entry by foreign firms introduces cost-saving innovations and services prices fall. Welfare increases dramatically by nearly eight percent. This large difference from the initial benchmark case reflects the fact that elimination of a pure rent wedge generates a small net gain in efficiency from resource reallocation, but most of the gross gains are transfers from the prior 
rent stream earned by the representative agent. ${ }^{9}$ In both cases consumer prices fall about seven percent. Note that while both scenarios increase returns to both labor and capital (non-labor value added), labor gains relatively more in the pure rent-wedge case. This suggests that one effect of the protected cartel is to restrain wages in relation to what they would be under full efficiency. Capital gains are relatively larger when the pure cost wedge is removed.

In the remainder of these counterfactual experiments, it is assumed that the price-wedge is an equal combination of the rent-generating and resource-using distortions (column 2 of Table 4). Thus, in this case the welfare impacts mix efficiency gains with rent losses for the representative agent. This baseline scenario for investment liberalization results in a four percent increase in welfare and a seven percent fall in the consumer price index. The gains from liberalization are skewed toward capital, the price of which increases seven percent. Five percent of the capital stock changes sector of employment. Real returns to labor increase by three percent and three percent of the labor force changes sector of employment.

The bottom part of Table 4 indicates impacts on major sectoral production shares. The figures in parentheses in the left-most part indicate benchmark output shares before any liberalization. Liberalization itself tends to favor relative output expansion in agriculture and services, while restraining the manufacturing and mining shares. Thus, the initial structure of protection for services actually restrains domestic output in that sector. The remaining columns compare these shares across FDI-liberalization cases. While these shares are essentially stable across benchmark assumptions, moving from the rent-wedge case to the efficiency-wedge case slightly favors agriculture and manufacturing, while reducing the share of services.

Table 5 provides liberalization scenarios by mode of service delivery, assuming an equal split of price markups between rents and costs in the benchmark. Assume that Tunisia eliminates all border barriers (mode one barriers) on tradable services, and does so on a non-discriminatory

\footnotetext{
${ }^{9}$ As discussed in Anderson and van Wincoop (2001), liberalization of trade costs that generate rents for home agents have smaller welfare impacts than liberalization of "real" trade costs that absorb resources.
} 
or most-favored-nation (MFN) basis. This would raise welfare, as measured by equivalent variation in the representative agent's real income, by about 1.2 percent. The model also simulates impacts on the real wage and return on capital. While both factors would gain, the benefits would be larger for capital (a 1.32 percent increase in price), with the real wage increasing by less than one percent. In terms of factor adjustment, 0.8 percent of the labor force and one percent of capital would turn over industry of employment.

The investment liberalization (mode 3) scenario shown in column 2 of Table 5 is the same as that discussed above (column 2 of Table 4). Finally, the aggregate impact of liberalizing both investment barriers and border barriers (modes one and three) is slightly more than additive as shown in column 3 , raising welfare by 5.3 percent. Note that roughly 75.5 percent of estimated welfare gains may be attributed to investment liberalization, while 23.0 percent are due to border liberalization. This leaves a small positive residual gain of 1.5 percent that stems from the fact that both types of barriers together interact to generate a larger income loss than they would separately. It is interesting that this interaction process affects labor and capital differently. The individual liberalization impacts on the real wage sum to less than the joint impact of full liberalization, suggesting that the barriers interact to restrain wages. The opposite is true for the real price of capital. Finally, note in the bottom panel that any policy reform expands the share of services compared to the initial benchmark. However, mode 1 liberalization favors manufacturing and mining over full liberalization in mode 1 and mode 3 , which favors agriculture and services. Indeed, full services liberalization would increase the services share of GDP from 40.7 percent to 43.6 percent, a large shift in relative output.

It is possible also to consider the gains from liberalizing individual service sectors, as reported in Table $6 .^{10}$ For this purpose we compute the impacts of liberalizing both mode 1 and mode 3 delivery options in six of the 11 tradable service sectors. About 41 percent of the welfare

\footnotetext{
${ }^{10}$ Note that sector-level reforms are assumed to occur in isolation while full liberalization entails the simultaneous liberalization of all modeled service sectors. The aggregate impact does not equal the sum of
} 
gains of full liberalization may be attributed to reforms in financial and transportation sectors. The impact of liberalization in business services, distribution, and communications are also substantial. Note that these individual trade reforms are not neutral with respect to factor prices. Opening up the construction sector would actually reduce the real wage moderately. Capital income would gain significantly from liberalization of transportation, business services, and finance.

The final set of scenarios compares liberalization of goods and services. Goods-trade liberalization is modeled as a non-discriminatory and unilateral elimination of the commodity tariffs given in Table 2. Results are shown in Table 7. Household welfare is estimated to increase by 1.5 percent, in contrast to the 5.3 percent gain from full services liberalization. As trade theory would predict, the gains are largely experienced by the abundant factor, labor, while there is relatively little change in the price of other value added. The wage increases nearly 19 percent while returns to capital increase 3.5 percent. Factor turnover is also quite high at 10 percent for both workers and capital. There is a significant increase in the manufacturing share of total output from 32.8 percent in the benchmark to 42.8 percent in the free goods-trade environment. Agriculture declines substantially as a relative component of output, as does services.

Liberalizing services barriers and goods tariffs simultaneously yields a potential gain in welfare of 6.7 percent. These gains are less than the sum available under the isolated liberalization packages, indicating that there is a somewhat offsetting interaction between the two commitments. Gains from joint liberalization, however, are more evenly distributed across labor and capital than they are in either individual reform. Thus, removal of goods tariffs strongly favors labor while removal of services barriers favors capital. Both factors experience significant real price increases with joint liberalization.

the sectoral impacts due to interactions between sectors with joint liberalization. 
Interestingly, the structure of output with full liberalization of both goods and services is closer to that with an isolated service liberalization than to one with solely goods tariff elimination, as noted in the bottom panel. Thus, in an important sense, removing commodity tariffs without services liberalization tends to "over-adjust" the economy toward manufacturing and away from agriculture and services. Freeing up services moves the structure back toward the fully efficient outcome in the final column. Indeed, a pure goods-trade liberalization results in a much greater movement of labor and more dramatic changes in the composition of production.

\section{CONCLUSIONS}

This paper considers how services liberalization differs from that of goods liberalization using an applied general equilibrium model of Tunisia's economy. Not surprisingly, goods-trade liberalization reorients production towards manufacturing (especially in textile and electronics) in line with Tunisia's benchmark comparative advantage. In contrast, the overall composition of production with service liberalization remains fairly stable, with only slight increases in manufacturing and service provision and a small decrease in agriculture and mining. The distribution of gain under service liberalization are more evenly distributed across factors than those under goods liberalization, where gains are strongly concentrated in the hands of workers (the abundant factor). Fewer workers are required to change positions to accommodate service liberalization, implying less impact on frictional unemployment. Thus, we might expect less political resistance to services liberalization relative to goods liberalization.

Interestingly, combining goods and services liberalization appears to offer the best of both worlds. The gains from jointly freeing up goods and services are nearly additive of the two independent reforms. Yet the overall structure of the economy remains similar to that of the benchmark, with relatively small changes in the employment location of workers. Services liberalization therefore eases the adjustment costs involved in the liberalization of goods trade as 
the expansion of economic activity would no longer be restrained by the lagging competitiveness of Tunisia's service sector.

The potential welfare implications of services liberalization are clearly positive and substantial. Even given modest assumptions about the current environment for trade in services, welfare (measured as equivalent variation) and GDP are both estimated to increase more than seven percent. These gains are more than three times the magnitude of the estimated gains from goods-trade liberalization alone. Further, perhaps 75 percent of services liberalization gains are to be achieved from the liberalization of foreign investment barriers that impede mode 3 delivery of services. Granting the right of establishment to foreign firms stands to increase real household income by four percent. In contrast, liberalization of cross-border trade in services (mode 1) results in a roughly one percent gain in household income.

The uncertainty surrounding estimated price wedges and the allocation of those wedges between rent and production inefficiency deserve further exploration. Improved estimates of services barriers are critical for a more accurate determination of the magnitude of the potential impacts of liberalization. It is important to note that cautious assumptions were made here about the existing distortions and the potential competitive effects and efficiency improvements with liberalization. It may be that a dramatic reform effort might bring even greater gains than those reported here. 

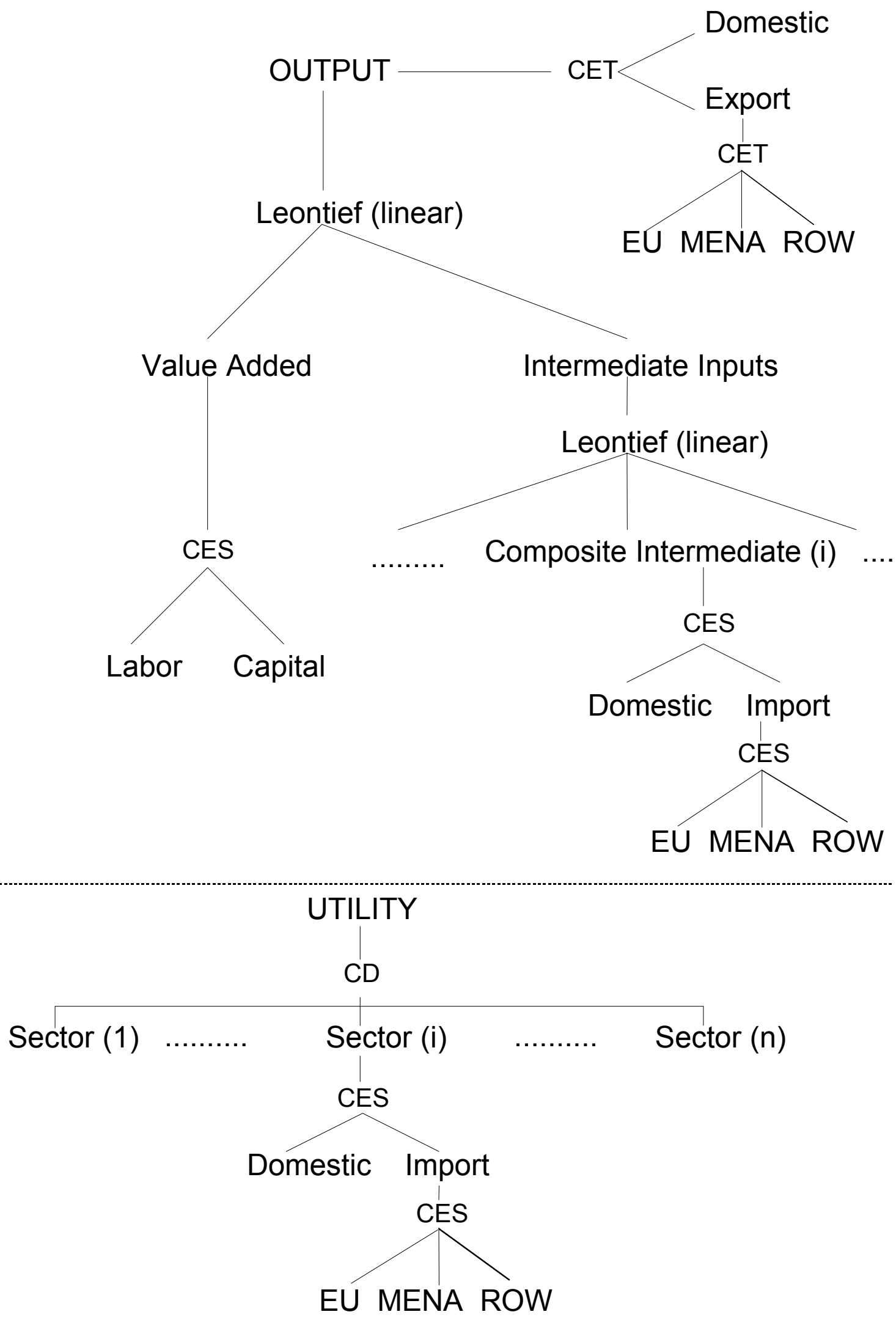


\section{A. Production}

\section{APPENDIX: MODEL EQUATIONS AND NOTATION}

1. Value Added Function

2. Imported Intermediates

3. Composite Intermediate

4. Final Goods Technology

5. Domestic \& Foreign Sales

6. Export Allocation

7. Marginal Cost Condition

\section{B. Utility}

8. Utility Function

9. Domestic \& Import Consumption (applies also to $\mathrm{G}_{\mathrm{i}}$ and $\mathrm{I}_{\mathrm{i}}^{\mathrm{F}}$ )

10. Import Allocation (applies also to $\mathrm{M}_{\mathrm{iG}}$ and $\mathrm{M}_{\mathrm{iI}}{ }^{\mathrm{F}}$ )

\section{Constraints and Balancing Items}

11. Agent's Budget Constraint

12. Government Budget Constraint

13. Current Account Balance

14. Product Market Clearance

15. Factor Market Clearance

16. Zero Profits

17. Supply Value Balance

$$
\begin{aligned}
& \mathrm{V}_{\mathrm{i}}=\left[\mathrm{a}_{\mathrm{Li}} \mathrm{L}_{\mathrm{i}}^{(\sigma \mathrm{i}-1) / \sigma \mathrm{i}}+\mathrm{a}_{\mathrm{Ki}} \mathrm{K}_{\mathrm{i}}^{(\sigma \mathrm{i}-1) / \sigma \mathrm{i}}\right]^{\sigma \mathrm{i} /(\sigma \mathrm{i}-1)} \\
& \mathrm{M}_{\mathrm{iN}}=\left[\sum_{\mathrm{r}} \delta_{\mathrm{ri}} \mathrm{m}_{\mathrm{riN}}{ }^{(\eta \mathrm{i}-1) / \eta \mathrm{i}}\right]^{\eta \mathrm{i} /(\mathrm{\eta} \mathrm{i}-1)} \\
& z_{j i}=\left[\gamma_{d i} d_{j i}{ }^{(\eta j-1) / \eta j}+\gamma_{m i} m_{j i}{ }^{(\eta j-1) / \eta j j}\right]^{\eta j /(\eta j-1)} \\
& \mathrm{Y}_{\mathrm{i}}=\min \left[\mathrm{z}_{1 \mathrm{i}} / \mathrm{a}_{1 \mathrm{i}}, . ., \mathrm{z}_{\mathrm{ni}} / \mathrm{a}_{\mathrm{ni}}, \mathrm{V}_{\mathrm{i}} / \mathrm{a}_{\mathrm{VA}}\right] \\
& \mathrm{Y}_{\mathrm{i}}=\left[\alpha_{\mathrm{Di}} \mathrm{D}_{\mathrm{i}}^{(\varepsilon \mathrm{i}-1) / \varepsilon \mathrm{i}}+\alpha_{\mathrm{Xi}} \mathrm{X}_{\mathrm{i}}^{(\varepsilon \mathrm{i}-1) / \varepsilon \mathrm{i}}\right]^{\varepsilon \mathrm{i} /(\varepsilon \mathrm{i}-1)} \\
& \mathrm{X}_{\mathrm{i}}=\left[\Sigma_{\mathrm{r}} \beta_{\mathrm{ri}} \mathrm{X}_{\mathrm{ri}}{ }^{(\mathrm{ei}-1) / \mathrm{ei}}\right]^{\mathrm{ei} /(\mathrm{ei}-1)} \\
& \left(1+\lambda_{\mathrm{i}}\right) \mathrm{c}_{\mathrm{i}} \mathrm{Y}_{\mathrm{i}}=\Sigma_{\mathrm{j}}\left(1+\mathrm{v}_{\mathrm{j}}\right) \mathrm{p}_{\mathrm{j}} \mathrm{d}_{\mathrm{ji}}+\Sigma_{\mathrm{j}} \Sigma_{\mathrm{r}}\left(1+\mathrm{u}_{\mathrm{j}}+\mathrm{t}_{\mathrm{rj}}\right) \mathrm{p}_{\mathrm{rj}}{ }^{\mathrm{m}} \mathrm{m}_{\mathrm{rji}} \\
& +\left(\mathrm{w}_{\mathrm{K}} \mathrm{K}_{\mathrm{i}}+\mathrm{w}_{\mathrm{L}} \mathrm{L}_{1 \mathrm{i}}\right)
\end{aligned}
$$

$$
\begin{aligned}
& \mathrm{U}=\Pi_{\mathrm{i}} \mathrm{C}_{\mathrm{i}}^{\mathrm{bi}} ; \Sigma_{\mathrm{i}} \mathrm{b}_{\mathrm{i}}=1 \\
& \mathrm{C}_{\mathrm{i}}=\left[\phi_{\mathrm{Di}} \mathrm{D}_{\mathrm{iC}}(\psi \mathrm{i}-1) / \psi \mathrm{i}+\phi_{\mathrm{MiC}} \mathrm{M}_{\mathrm{iC}}{ }^{(\psi \mathrm{i}-1) / \psi \mathrm{i}}\right]^{\psi \mathrm{i} / \psi \mathrm{i}-\mathrm{i}} \\
& \mathrm{M}_{\mathrm{iC}}=\left[\sum_{\mathrm{r}} \delta_{\mathrm{ri}} \mathrm{M}_{\mathrm{ric}}{ }^{(\eta \mathrm{i}-1) / \eta \mathrm{i}}\right]^{\eta \mathrm{i} / \eta \mathrm{i}-1}
\end{aligned}
$$

$$
\begin{aligned}
& \Sigma_{\mathrm{i}} \widetilde{\mathrm{p}}_{\mathrm{i}}^{\mathrm{C}} \mathrm{C}_{\mathrm{i}}=\mathrm{w}_{\mathrm{K}} \overline{\mathrm{E}}_{\mathrm{K}}+\mathrm{w}_{\mathrm{L}} \Sigma_{\mathrm{i}} \mathrm{L}_{\mathrm{i}}+-\Sigma_{\mathrm{i}} \widetilde{\mathrm{p}}_{\mathrm{i}}^{\mathrm{IF}} \mathrm{I}_{\mathrm{i}}^{\mathrm{F}} \\
& -\Sigma_{\mathrm{i}} \mathrm{p}_{\mathrm{i}} \mathrm{I}_{\mathrm{i}}^{\mathrm{I}}-\mathrm{r}^{\mathrm{F}} \mathrm{K}^{\mathrm{F}}-\mathrm{D}+\Sigma_{\mathrm{i}} \mathrm{V}_{\mathrm{i}} \mathrm{Y}_{\mathrm{i}} \\
& \Sigma_{\mathrm{i}} \widetilde{\mathrm{p}}_{\mathrm{i}}^{\mathrm{G}} \mathrm{G}_{\mathrm{i}}=\mathrm{D}+\Sigma_{\mathrm{i}} \tau_{\mathrm{Vi}} \widetilde{\mathrm{p}}_{\mathrm{i}}^{\mathrm{C}} \mathrm{V}_{\mathrm{i}}+\Sigma_{\mathrm{i}} \Sigma_{\mathrm{r}} \mathrm{t}_{\mathrm{ri}} \mathrm{p}_{\mathrm{ri}}{ }^{\mathrm{m}}\left(\mathrm{M}_{\mathrm{riC}}+\mathrm{M}_{\mathrm{ril}}{ }^{\mathrm{F}}\right) \\
& 0=\Sigma_{\mathrm{r}} \Sigma_{\mathrm{i}}(1 / \mathrm{e})\left(\mathrm{p}_{\mathrm{ri}}{ }^{\mathrm{m}} \mathrm{M}_{\mathrm{ri}}-\mathrm{p}_{\mathrm{ri}}{ }^{\mathrm{x}} \mathrm{X}_{\mathrm{ri}}-\mathrm{w}_{\mathrm{L}}{ }^{\mathrm{F}} \mathrm{L}^{\mathrm{F}}+\mathrm{r}^{\mathrm{F}} \mathrm{K}^{\mathrm{F}}\right) \\
& \mathrm{S}_{\mathrm{i}}=\Sigma_{\mathrm{j}} \mathrm{a}_{\mathrm{ij}} \mathrm{Y}_{\mathrm{j}}+\mathrm{G}_{\mathrm{i}}+\mathrm{I}_{\mathrm{i}}^{\mathrm{F}}+\mathrm{I}_{\mathrm{i}}^{\mathrm{I}}+\mathrm{C}_{\mathrm{i}} \\
& \Sigma_{\mathrm{i}} \mathrm{K}_{\mathrm{i}}=\overline{\mathrm{E}}_{\mathrm{K}} ; \Sigma_{\mathrm{i}} \mathrm{L}_{\mathrm{i}}=\overline{\mathrm{E}}_{1 \mathrm{~L}} \\
& \mathrm{p}_{\mathrm{i}} \mathrm{D}_{\mathrm{i}}+\sum_{\mathrm{r}} \mathrm{p}_{\mathrm{ri}}{ }^{\mathrm{x}} \mathrm{X}_{\mathrm{ri}}=\mathrm{c}_{\mathrm{i}} \mathrm{Y}_{\mathrm{i}} \\
& \widetilde{p}_{i} S_{i}=\widetilde{p}_{i}^{Z} \Sigma_{j} a_{i j}\left(1+v_{i}\right) Y_{j}+\widetilde{p}_{i}^{C} D_{i C}+\widetilde{p}_{i}^{I F} D_{i I}{ }^{F}+\widetilde{p}_{i}^{G} D_{i G} \\
& +\widetilde{\mathrm{p}}_{\mathrm{i}}^{\mathrm{IF}} \mathrm{I}_{\mathrm{i}}^{\mathrm{I}}+\sum_{\mathrm{r}}\left(1+\mathrm{u}_{\mathrm{i}}+\mathrm{t}_{\mathrm{ri}}\right) \mathrm{p}_{\mathrm{ri}}{ }^{\mathrm{m}}\left(\mathrm{M}_{\mathrm{riC}}+\mathrm{M}_{\mathrm{riG}}+\mathrm{M}_{\mathrm{ril}}{ }^{\mathrm{F}}\right)
\end{aligned}
$$




\section{Price Relationships and Identities}

18. Components of Domestic Sales

19. Components of Import Sales

20. Domestic Price of Intermediate Imports (holds also for imports for $\mathrm{G}$ )

21. Domestic Price of Imports for C (holds also for imports for $\mathrm{I}^{\mathrm{F}}$ )

22. Consumer Price of Domestic Goods (holds also for purchases for $\mathrm{I}^{\mathrm{F}}$ )

23. Capital-Market Equilibrium

$$
\begin{aligned}
& \mathrm{D}_{\mathrm{i}}=\mathrm{D}_{\mathrm{iC}}+\mathrm{D}_{\mathrm{iI}}{ }^{\mathrm{F}}+\mathrm{I}_{\mathrm{i}}^{\mathrm{I}}+\mathrm{D}_{\mathrm{iG}} \\
& \mathrm{M}_{\mathrm{i}}=\mathrm{M}_{\mathrm{iN}}+\mathrm{M}_{\mathrm{iC}}+\mathrm{M}_{\mathrm{iI}}{ }^{\mathrm{F}}+\mathrm{M}_{\mathrm{iG}}
\end{aligned}
$$

$\mathrm{p}_{\mathrm{ri}}{ }^{\mathrm{N}}=\left(1+\mathrm{u}_{\mathrm{i}}+\mathrm{t}_{\mathrm{ri}}\right) \mathrm{p}_{\mathrm{ri}}^{\mathrm{m}}$

$\mathrm{p}_{\mathrm{ri}}{ }^{\mathrm{C}}=\left(1+\mathrm{u}_{\mathrm{i}}+\mathrm{t}_{\mathrm{ri}}\right) \mathrm{p}_{\mathrm{ri}}{ }^{\mathrm{m}}$

$\mathrm{p}_{\mathrm{i}}^{\mathrm{C}}=\left(1+\mathrm{v}_{\mathrm{i}}\right) \mathrm{p}_{\mathrm{i}}$

$\tau_{\mathrm{K} 1}+\mathrm{w}_{\mathrm{K} 1}=\ldots=\tau_{\mathrm{Kn}}+\mathrm{w}_{\mathrm{Kn}}($ mobile capital sectors $)$

\section{LIST OF VARIABLES}

$\mathrm{L}_{\mathrm{i}} \quad$ Domestic labor inputs, sector $\mathrm{i}(\mathrm{i}=1, . ., 34)$

$\mathrm{K}_{\mathrm{i}} \quad$ Capital (other value added) inputs, both mobile and immobile

$\mathrm{V}_{\mathrm{i}} \quad$ Value added

$\mathrm{M}_{\mathrm{i}} \quad$ Total imports

$\mathrm{M}_{\mathrm{ri}} \quad$ Imports from region $\mathrm{r}(\mathrm{r}=\mathrm{EU}, \mathrm{MENA}, \mathrm{ROW})$

$\mathrm{M}_{\mathrm{iN}} \quad$ Imports of commodity i for intermediate use

$\mathrm{m}_{\mathrm{riN}} \quad$ Imports for intermediate use from region $\mathrm{r}(\mathrm{r}=\mathrm{EU}$, MENA, ROW $)$

$\mathrm{z}_{\mathrm{ji}} \quad$ Composite intermediate input of $\mathrm{j}$ into $\mathrm{i}(\mathrm{j}=1, \ldots, 34)$

$\mathrm{d}_{\mathrm{ji}}, \mathrm{m}_{\mathrm{ji}} \quad$ Intermediate usages of domestic and imported goods

$\mathrm{Y}_{\mathrm{i}} \quad$ Output of good i

$\mathrm{D}_{\mathrm{i}}, \mathrm{X}_{\mathrm{i}} \quad$ Output for domestic sales and exports

$\mathrm{D}_{\mathrm{iC}}, \mathrm{D}_{\mathrm{iG}}, \mathrm{D}_{\mathrm{iI}}{ }^{\mathrm{F}} \quad$ Domestic sales: private and public consumption, capital formation

$\mathrm{X}_{\mathrm{ri}} \quad$ Exports of good $\mathrm{i}$ to region $\mathrm{r}$

$\mathrm{c}_{\mathrm{i}} \quad$ Index of marginal cost of production

$\mathrm{p}_{\mathrm{i}} \quad$ Domestic producer price index

$\widetilde{\mathrm{p}}_{\mathrm{i}}^{\mathrm{Z}}, \widetilde{\mathrm{p}}_{\mathrm{i}}^{\mathrm{C}}, \widetilde{\mathrm{p}}_{\mathrm{i}}^{\mathrm{IF}}, \widetilde{\mathrm{p}}_{\mathrm{i}}^{\mathrm{G}} \quad$ Domestic price indexes (home and imported prices)

$\mathrm{w}_{\mathrm{K}}, \mathrm{w}_{\mathrm{L}} \quad$ Factor price indexes

U Utility

$\widetilde{\mathrm{p}}_{\mathrm{i}} \quad$ Composite price index for total domestic supply

$\mathrm{C}_{\mathrm{i}}, \mathrm{G}_{\mathrm{i}} \quad$ Private and public consumption

$\mathrm{I}_{\mathrm{i}}{ }^{\mathrm{F}}, \mathrm{I}_{\mathrm{i}}^{\mathrm{I}} \quad$ Fixed capital formation and inventory investment

$\mathrm{M}_{\mathrm{iC}}, \mathrm{M}_{\mathrm{iG}} \quad$ Imports for private and public consumption 

$\mathrm{M}_{\mathrm{iI}}^{\mathrm{F}}$
Imports for fixed capital formation
$\mathrm{M}_{\mathrm{riC}}, \mathrm{M}_{\mathrm{riG}}$
Imports for private and public consumption from region $r$
$\mathrm{M}_{\text {riI }}{ }^{\mathrm{F}}$
Imports for fixed capital formation from region $r$
$\mathrm{K}^{\mathrm{F}}$
Net payments on foreign capital holdings
e
Real exchange rate (price index for foreign exchange)
$\mathrm{B}$
Current-account balance
D
Government budget deficit (held fixed)
$\mathrm{S}_{\mathrm{i}}$
Supply on domestic market $\left(D_{i}+M_{i}\right)$
$\mathrm{p}_{\mathrm{ri}}^{\mathrm{N}}$
Domestic price index for intermediate imports
$\mathrm{p}_{\mathrm{ri}}{ }^{\mathrm{C}}, \mathrm{p}_{\mathrm{ri}}{ }^{\mathrm{G}}$
Domestic price indexes for imports of private and public consumption
$\mathrm{p}_{\text {riI }}^{\mathrm{F}}$
Domestic price index for imports for gross capital formation
$\mathrm{p}_{\mathrm{i}}^{\mathrm{C}}, \mathrm{p}_{\mathrm{iI}}^{\mathrm{F}}$
Price index for private consumption/fixed capital of domestic goods
$\mathrm{p}_{\mathrm{ri}}$
Producer price index for goods exported to region $r$

\section{LIST OF PARAMETERS}

$\sigma_{\mathrm{i}}$

$\eta_{\mathrm{a}}$

$\eta_{\mathrm{i}}$

$\eta_{\mathrm{j}}$

$\varepsilon_{\mathrm{i}}$

$\mathrm{e}_{\mathrm{i}}$

$\psi_{\mathrm{i}}$

$\mathrm{t}_{\mathrm{ri}}$

$\mathrm{u}_{\mathrm{i}}$

$\mathrm{v}_{\mathrm{i}}$

$\lambda_{\mathrm{i}}$

$\overline{\mathrm{E}}_{\mathrm{K}}, \overline{\mathrm{E}}_{1 \mathrm{~L}}$

$\mathrm{p}_{\mathrm{ri}}^{\mathrm{m}}$

$\mathrm{p}_{\mathrm{ri}}^{\mathrm{x}}$

$r^{\mathrm{F}}$
Substitution elasticity between capital and labor

Substitution elasticity between intermediates and value added

Armington elasticity on imports between regions

Substitution elasticity between domestic and imported intermediates

Transformation elasticity between domestic and exported output

Transformation elasticity on exports between regions

Substitution elasticity between domestic and imported consumption

Tariff rate on imports from region $\mathrm{r}\left(\mathrm{t}_{\mathrm{ri}}=0\right.$ for service sectors $)$

Resource-using services border barriers ( $\mathrm{u}_{\mathrm{i}}=0$ for non-service sectors)

Service rents on output ( $\mathrm{v}_{\mathrm{i}}=0$ for non-service sectors)

Service resource-using barriers on output ( $\lambda_{\mathrm{i}}=0$ for non-service sectors)

Endowment of capital and labor

Price of imports from region $\mathrm{r}$

Price of exports in region $r$

Price of foreign capital payments 


\section{References}

Anderson, James E. and Eric van wincoop, 2001, "Borders, Trade, and Welfare," forthcoming in Susan Collins and Dani Rodrik, editors, Brookings Trade Forum 2001.

Bahlous, Mejda and Mustapha K. Nabli, 2000, "Financial Liberalization and Financing Constraints on the Corporate Sector in Tunisia," Working Paper No 2005, Economic Research Forum for the Arab Countries.

Brown, Drusilla, Alan Deardorff, Alan Fox, and Robert M. Stern, 1996, "Computational Analysis of Goods and Services Liberalization in the Uruguay Round," in Will Martin and L. Alan Winters, editors, The Uruguay Round and Developing Economies, Cambridge University Press.

Brown, Drusilla K., and Robert M. Stern, 2001, "Measurement and Modeling of the Economic Effects of Trade and Investment Barriers in Services," Review of International Economics, 9: 262-86.

Dee, Philippa and Kevin Hanslow, 2001, "Multilateral Liberalization of Services Trade," in Robert M. Stern, editor, Services in the International Economy, University of Michigan Press, Ann Arbor.

Dee, Philippa, Alexis Hardin and Leanne Holmes, 2000, "Issues in the Application of CGE Models to Services Trade Liberalization," in Christopher Findlay and Tony Warren, editors, Impediments to Trade in Services: Measurement and Policy Implications, Routledge, London and New York.

Francois, Joseph, 1999, “A Gravity Approach to Measuring Services Protection,” Manuscript, Erasmus University.

Francois, Joseph and Ian Wooton, 2001, "Market Structure, Trade Liberalization, and the GATS," European Journal of Political Economics 17: 389-402.

Goaied, Mohamed, (1999), "Cost-frontier Analysis of Tunisian Commercial Banking Sectors," manuscript.

Harrison, G.W., R. Jones, L. Kimbell Jr., and R. Wigle. 1993. "How Robust is Applied General Equilibrium Modeling?" Journal of Policy Modeling 15: 99-115. NOT IN TEXT

Hertel, Thomas W., 2000, "Potential Gains from Reducing Trade Barriers in Manufacturing, Services and Agriculture," in Multilateral Trade Negotiations: Issues for the Millenium Round, St. Louis: Federal Reserve Bank of St. Louis.

Hoekman, Bernard, 1995, "Tentative First Steps: An Assessment of the Uruguay Round Agreement on Services,” World Bank Policy Research Working Paper 1455. Washington DC.

Hoekman, Bernard, 2000, "The Next Round of Services Negotiations: Identifying Priorities and Options," in Multilateral Trade Negotiations: Issues for the Millenium Round, St. Louis: Federal Reserve Bank of St. Louis. 
Hoekman, Bernard and Denise Eby Konan, 2000, "Rents, Red Tape, and Regionalism: Economic Effects of Deeper Integration," in B. Hoekman and J. Zarrouk, editors, Catching Up with the Competition: Trade Policy Challenges and Options for the Middle East and North Africa, Ann Arbor: University of Michigan Press.

Institute National De La Statistique (INS), 1998, Les Comptes de la Nation, agregats et tableaux d'ensemble 1993-1997, Tunis: INS Press.

Kalirajan, Kaleeswaran, Greg McGuire, Duc Nguyen-Hong, and Michael Schuele, 2000, "The Price Impact of restrictions on Banking Services," in Christopher Findlay and Tony Warren, editors, Impediments to Trade in Services: Measurement and Policy Implications, London and New York: Routledge.

Karsenty, Guy, 2000, "Assessing Trade in Services by Mode of Supply," in: GATS 2000: New Directions in Services Trade Liberalization, Pierre Sauve and Robert M. Stern, editors, Washington DC: Brookings Institution Press.

Kehoe, Timothy J., 2002, "An Evaluation of the Performance of Applied General Equilibrium Models of the Impact of NAFTA," Federal Reserve Bank of Minneapolis, Research Department Staff Report.

Konan, Denise Eby and Keith E. Maskus, 1997, "A Computable General Equilibrium Analysis of Egyptian Trade Liberalization Scenarios," in Ahmad Galal and Bernard Hoekman, editors, Regional Partners, Global Markets: Limits and Possibilities of the EuroMediterranean Agreements, London: Center for Economic Policy Research in Europe (CEPR) and Washington DC: Brookings Institution Press. NOT IN TEXT

Konan, Denise Eby and Keith E. Maskus. 2000. "Joint Trade Liberalization and Tax Reform in a Small Open Economy: The Case of Egypt," Journal of Development Economics 61: $365-92$.

Lipsey, Robert, 2001, "The New Economy: Theory and Measurement," paper for $27^{\text {th }}$ Annual PAFTAD Conference: The New Economy: Challenges for East Asia and the Pacific, Canberra, Australia.

Markusen, James, Thomas F. Rutherford and David Tarr, 1999, "Foreign Direct Investment in Services and the Domestic Market for Expertise," World Bank Policy Research Working Paper 2431, Washington DC: The World Bank.

Maskus, Keith E. and Denise Eby Konan. 1997. "Trade Liberalization in Egypt," Review of Development Economics, 1:275-93.

Rodrik, Dani, 2001, “Trading in Illusions,” Foreign Policy, March/April, 54-62.

Rutherford, T., E.E. Rutstrom, and David Tarr. 1995. "The Free Trade Agreement Between Tunisia and the European Union," World Bank, manuscript.

Warren, Tony and Christopher Findlay, 2000, "Measuring Impediments to Trade in Services," in: GATS 2000: New Directions in Services Trade Liberalization, Pierre Sauve and Robert M. Stern, editors, Washington DC: Brookings Institution Press. 
Vittas, Dimitri, 1995, “The Insurance Sector in Tunisia, Financial Sector Development Department,” World Bank Working Paper, March 1995.

World Bank, 2000, Tunisia: Social and Structural Review 2000: Integrating into the World Economy and Sustaining Economic and Social Progress, World Bank, Washington, DC.

Zarrouk, Jamel, 2000, "Regulatory Regimes and Trade Costs," in Bernard Hoekman and Jamel Zarrouk, Editors, Catching Up with the Competition: Trade Opportunities and Challenges for Arab Countries, Ann Arbor: University of Michigan Press. 
TABLE 1: SECTORAL OUTPUT AND FACTOR SHARES (\%)

Household Intermediate

Production Imports Consumption Consumption

Exports

\begin{tabular}{lrrrrr}
\hline AGGREGATE SECTORS (\% of total) & & & & \\
Agriculture and Fishing & 17.5 & 10.2 & 32.4 & 20.1 & 6.6 \\
Manufacturing & 30.0 & 63.2 & 29.7 & 51.3 & 55.3 \\
Utilities, Mining, Petroleum & 5.8 & 5.8 & 4.0 & 10.9 & 6.8 \\
Services & 46.7 & 20.8 & 33.8 & 17.7 & 31.2 \\
& & & & & \\
SERVICE SECTORS (\% of total) & & & & & \\
Construction & 8.2 & 0.0 & 0.3 & 0.4 & 0.0 \\
Distribution/Commerce & 6.9 & 0.0 & 0.0 & 0.0 & 0.0 \\
Transportation & 5.6 & 2.7 & 5.7 & 4.3 & 8.7 \\
Communication & 1.0 & 0.1 & 0.3 & 1.7 & 0.4 \\
Hotel & 1.5 & 0.0 & 3.9 & 0.1 & 0.0 \\
Restaurant & 4.1 & 0.0 & 10.9 & 0.0 & 0.0 \\
Finance & 2.5 & 0.2 & 0.1 & 4.8 & 0.3 \\
Insurance & 0.3 & 0.2 & 0.3 & 0.6 & 0.0 \\
Business & 1.4 & 2.1 & 0.1 & 2.5 & 2.5 \\
Real Estate & 2.6 & 0.0 & 5.0 & 1.3 & 0.0 \\
Repair & 1.3 & 0.0 & 1.1 & 1.8 & 0.0 \\
Health and Education & 2.0 & 0.0 & 4.9 & 0.2 & 0.0 \\
Public & 9.0 & 0.0 & 0.6 & 0.0 & 0.0 \\
Other Services & 0.2 & 0.0 & 0.6 & 0.0 & 0.0 \\
Tourism & -- & 15.4 & -- & -- & 19.3
\end{tabular}

Institute National de la Statistique, 1998, Les Comptes de la Nation Base 1983, agregats et tableaux d'ensemble 1993$\underline{1997 .}$ 
Table 2: Benchmark Trade Shares and Tariffs

\begin{tabular}{lcccc} 
& \multicolumn{2}{c}{ EU Trade Share (\%) } & \multicolumn{2}{c}{$\begin{array}{c}\text { Trade-Weighted } \\
\text { Import Tariff }\end{array}$} \\
\hline \multicolumn{1}{c}{ Sectors } & Imports & Exports & \multicolumn{2}{c}{ EU Rest of World } \\
\hline Agriculture & 38.7 & 68.7 & 13.5 & 13.0 \\
Process Foods & 55.3 & 71.9 & 17.6 & 18.5 \\
Chemicals and Glass & 48.8 & 24.0 & 21.1 & 23.6 \\
Non-Ferreous Metals & 57.7 & 70.4 & 15.3 & 21.2 \\
Metalwork & 67.8 & 58.8 & 15.3 & 17.5 \\
Machinery & 77.0 & 86.0 & 6.5 & 8.5 \\
Automobiles \& Trucks & 87.6 & 40.8 & 6.3 & 10.8 \\
Automobile parts & 57.1 & 71.0 & 0.1 & 1.7 \\
Electrical Parts & 66.4 & 50.4 & 4.3 & 7.8 \\
Electronics & 66.4 & 50.4 & 4.3 & 7.8 \\
Household Appliances & 66.4 & 50.4 & 4.3 & 7.8 \\
Chemicals & 75.7 & 39.2 & 9.0 & 10.3 \\
Clothing \& Textiles & 92.3 & 94.8 & 17.7 & 21.6 \\
Leather & 93.3 & 96.6 & 25.1 & 28.3 \\
Wood & 41.1 & 66.7 & 16.4 & 16.6 \\
Paper & 74.4 & 20.6 & 11.1 & 5.3 \\
Plastics & 72.9 & 28.0 & 14.5 & 18.7 \\
Other Manufacturing & 72.9 & 76.2 & 8.1 & 15.8 \\
Mining & 30.6 & 86.0 & 17.4 & 2.5 \\
Petroleum & 63.3 & 38.7 & 12.2 & 20.2 \\
Services & 70.0 & 76.0 & &
\end{tabular}

Table 3: Barriers to Trade in Services (NTB ad valorem price equivalent \%)

Mode 1

Cross-border trade

Distribution

Transportation

Communications

Hotel

Restaurant

Finance

Insurance

Business, Insurance \& Leasing

Real Estate

Repair

Health and Education

Public

Other Services $n t$

$n t$

Mode 3

Foreign Presence

3

5

3

30

$200 \quad 30$

$n t \quad 3$

$n t \quad 3$

$30 \quad 30$

$50 \quad 50$

$10-10$

$10 \quad 10$

nt 3

$n t \quad n t$

$n t \quad n t$

$n t \quad n t$

$n t$ non-traded modes of supply 
Table 4: Liberalization of Foreign Direct Investment in Services

\begin{tabular}{|c|c|c|c|}
\hline & $\begin{array}{l}\text { Rent wedge: } 100 \% \\
\text { Cost wedge: } 0 \%\end{array}$ & $\begin{array}{l}\text { Baseline Scenario } \\
\text { Rent wedge: } 50 \% \\
\text { Cost wedge: } 50 \%\end{array}$ & $\begin{array}{l}\text { Rent wedge: } 0 \% \\
\text { Cost wedge: } 100 \%\end{array}$ \\
\hline \multicolumn{4}{|l|}{ Macroeconomic Variables (\% change) } \\
\hline Welfare, Household Income (EV) & 0.33 & 4.00 & 7.68 \\
\hline Consumer price index $(\mathrm{CPI})$ & -7.09 & -7.11 & -7.13 \\
\hline Price of Labor & 4.39 & 3.19 & 2.04 \\
\hline Price of Capital & 6.55 & 6.99 & 7.43 \\
\hline Labor turnover & 3.44 & 3.42 & 3.78 \\
\hline Capital Turnover & 4.87 & 4.90 & 5.06 \\
\hline \multicolumn{4}{|l|}{ Production (share of GDP) } \\
\hline Agriculture $($ bench $=19.5$ percent $)$ & 21.1 & 21.2 & 21.3 \\
\hline Manufacturing (32.8 percent) & 28.5 & 28.7 & 28.9 \\
\hline Mining and Utilities $\quad(7.0$ percent $)$ & 6.8 & 6.8 & 6.7 \\
\hline Services $\quad$ (40.7 percent) & 43.6 & 43.3 & 43.1 \\
\hline
\end{tabular}

Table 5: Baseline Services Liberalization Scenarios

\begin{tabular}{|c|c|c|c|}
\hline & $\begin{array}{c}\text { Border } \\
\text { Liberalization }\end{array}$ & $\begin{array}{c}\text { Investment } \\
\text { Liberalization }\end{array}$ & $\begin{array}{c}\text { Full Service } \\
\text { Liberalization }\end{array}$ \\
\hline \multicolumn{4}{|l|}{ Macroeconomic Variables (\% change) } \\
\hline Welfare, Household Income (EV) & 1.22 & 4.00 & 5.30 \\
\hline Consumer price index & -1.02 & -7.11 & -8.04 \\
\hline Price of Labor & 0.57 & 3.19 & 4.23 \\
\hline Price of Capital & 1.32 & 6.99 & 8.23 \\
\hline Labor turnover & 0.78 & 3.42 & 3.73 \\
\hline Capital Turnover & 0.98 & 4.90 & 5.35 \\
\hline \multicolumn{4}{|l|}{ Production (share of GDP) } \\
\hline Agriculture $\quad($ bench $=19.5$ percent $)$ & 19.9 & 21.2 & 21.4 \\
\hline Manufacturing $\quad$ (32.8 percent) & 31.7 & 28.7 & 28.2 \\
\hline Mining and Utilities (7.0 percent) & 7.1 & 6.8 & 6.8 \\
\hline (40.7 percent) & 41.3 & 43.3 & 43.6 \\
\hline
\end{tabular}


Table 6: Baseline Service liberalization (Mode 1 and Mode 3), by sector

\begin{tabular}{lccccccc}
\hline & $\begin{array}{c}\text { Commun- } \\
\text { ications }\end{array}$ & $\begin{array}{c}\text { Construc- } \\
\text { tion }\end{array}$ & $\begin{array}{c}\text { Transport- } \\
\text { ation }\end{array}$ & $\begin{array}{c}\text { Business, } \\
\text { Insurance, \& } \\
\text { Leasing }\end{array}$ & $\begin{array}{c}\text { Distrib- } \\
\text { ution }\end{array}$ & $\begin{array}{c}\text { All } \\
\text { Finance }\end{array}$ & $\begin{array}{c}\text { Service } \\
\text { Sectors }\end{array}$ \\
\hline Welfare (EV) & 0.46 & 0.32 & 1.09 & 0.60 & 0.44 & 1.08 & 5.30 \\
Price Labor & 0.90 & -0.13 & 0.62 & 0.66 & 1.23 & 0.60 & 4.23 \\
Price Capital & 0.46 & 0.10 & 1.44 & 1.69 & 0.54 & 2.29 & 8.23 \\
Labor Turnover & 0.35 & 0.15 & 1.03 & 1.34 & 0.68 & 1.84 & 3.73 \\
Capital Turnover & 0.40 & 0.11 & 1.23 & 1.89 & 0.89 & 2.62 & 5.35 \\
\hline
\end{tabular}

Table 7: Comparing Goods and Services Liberalization (Baseline Case)

\begin{tabular}{|c|c|c|c|}
\hline & $\begin{array}{c}\text { Goods } \\
\text { Liberalization } \\
\text { (Eliminate tariff) }\end{array}$ & $\begin{array}{c}\text { Services } \\
\text { Liberalization } \\
\text { (Mode } 1 \& 3 \text { ) }\end{array}$ & $\begin{array}{l}\text { Goods and } \\
\text { Services } \\
\text { Liberalization }\end{array}$ \\
\hline \multicolumn{4}{|l|}{ Macroeconomic Variables (\% change) } \\
\hline Welfare, Household Income (EV) & 1.52 & 5.30 & 6.67 \\
\hline Consumer price index & -1.07 & -8.04 & -9.07 \\
\hline Price of Labor & 18.93 & 4.23 & 17.67 \\
\hline Price of Capital & 3.46 & 8.23 & 13.61 \\
\hline Labor turnover & 9.83 & 3.73 & 3.40 \\
\hline Capital Turnover & 10.38 & 5.35 & 5.89 \\
\hline \multicolumn{4}{|l|}{ Production (share of GDP) } \\
\hline Agriculture $\quad($ bench $=19.5$ percent $)$ & 15.3 & 21.4 & 19.1 \\
\hline Manufacturing $\quad$ (32.8 percent) & 42.8 & 28.2 & 33.6 \\
\hline Mining and Utilities (7.0 percent) & 5.2 & 6.8 & 5.6 \\
\hline Services $\quad$ (40.7 percent) & 36.7 & 43.6 & 41.7 \\
\hline
\end{tabular}

